\title{
Ethnobotanical Survey of Wild Edible Plants and Their Contribution for Food Security Used by Gumuz People in Kamash Woreda; Benishangul Gumuz Regional State; Ethiopia
}

\author{
Dessalegn Ayele Amente \\ Department of Biology, College of Natural and Computational Science, Assosa University, Assosa, Ethiopia
}

Email address:

dessalegnayele2011@gmail.com

To cite this article:

Dessalegn Ayele Amente. Ethnobotanical Survey of Wild Edible Plants and Their Contribution for Food Security Used by Gumuz People in Kamash Woreda; Benishangul Gumuz Regional State; Ethiopia. Journal of Food and Nutrition Sciences. Vol. 5, No. 6, 2017, pp. $217-224$. doi: $10.11648 /$ j.jfns.20170506.12

Received: August 31, 2017; Accepted: September 23, 2017; Published: November 14, 2017

\begin{abstract}
The aims of this study was documenting and assessing the utilization of the food plants used by the Gumuz community in western Ethiopia. Informants were sampled from selected kebeles randomly. Semi-structured interview, questionnaires, focus group discussion and field observations were tools of data collection. Descriptive statistics, preference ranking, direct matrix ranking, and informant consensus were used to analyze the data. Total of 35 families, 49 genera with 60 species of wild edible plants were collected in the study area. Most of them are shrubs (36.67\%) followed by trees and herbs with $28.33 \%$ and $28.33 \%$ respectively. Oxythenantra abysinica was the most preferred species. Wild edible plants are threatened due to various human and natural causes. Thus, public awareness and community based management is need to be encouraged by government and Non Government Organizations at all levels.
\end{abstract}

Keywords: Ethnobotany, Food Security, Wild Edible Plants

\section{Introduction}

Different People of the world feed upon various types of food depending on their culture. Thousands of species of wild fruits, leaves, seed, root and tuber are consumed as food worldwide. Wild edible plants (WEP) provide staple food for indigenous people, serve as complementary food for nonindigenous people and offer an alternative source of cash income for poor communities [1].

It is unclear how the current global food system will meet the growing demands of a population expected to reach 9 billion people by 2050 [2]. In the present context of climate change, ongoing loss of species and genetic diversity, soil degradation, increasing urbanization, social conflict and extreme poverty, there is an urgent need for collective action to address food and nutrition security at the global level [3].

WEPs play a great role in ensuring food security and improve the nutrition in the diets of many people in developing countries [2]. Millions of people in many developing countries do not have enough food to meet their daily needs and a further more people are deficient in one or more micronutrients. Thus, in most cases rural communities depend on wild resources including WEPs to meet their food needs in periods of food crisis [4].

More recently, some ethno botanical studies have undertaken in some parts of Ethiopia. However, the majority of these studies have dealt with medicinal species and little emphasis has been paid to wild edible plants [4]. Since traditional knowledge on WEPs is being eroded through acculturation and the loss of plant biodiversity along with indigenous people and their cultural background, promoting research on wild food plants is crucial in order to safeguard this information for future [5]. WEP species are still largely ignored in land use planning and implementation, in economic development, and in biodiversity conservation endeavors. Therefore, this study was aimed to document such economic potentials for food security used by the Gumuz community of Kamash Woreda in western part of Ethiopia. 


\section{Materials and Methods}

\subsection{Description of the Study Area}

The study was conducted during 2014-2016in Kamash Woreda of Benishangul Gumuz Regional State which is located in the mid-western part of the Ethiopia. The Woreda is located on the western slopes of the Didessa River, with elevations ranging from approximately 2000 meters above sea level in the west to just under 1000 meters at the bottom of the Didessa valley. It is bordered by the Didessa River on the east which separates it from Yaso and Belo Jegonfoy, by the Oromia Region on the south and west, and by Agalo Meti on the northwest.
The Central Statistical Agency national census reported a total population for this Woreda 17,883, of which 5,917 $(33.09 \%)$ is urban dwellers and population density of 6.8 people per square kilometer which is less than the Zone average of 7.61. The two largest ethnic groups reported in Kamash Woreda were the Gumuz (81.4\%), and the Oromo $(17.4 \%)$; all other ethnic groups made up $1.2 \%$ of the population [6].

The average rain fall of the region is $1200 \mathrm{~mm}$ in the area around Assosa and reduced towards north and west to about $800 \mathrm{~mm}$. Vegetation of the area is still nearly intact and has comparable vascular plant diversity to other floristic regions in Ethiopia.

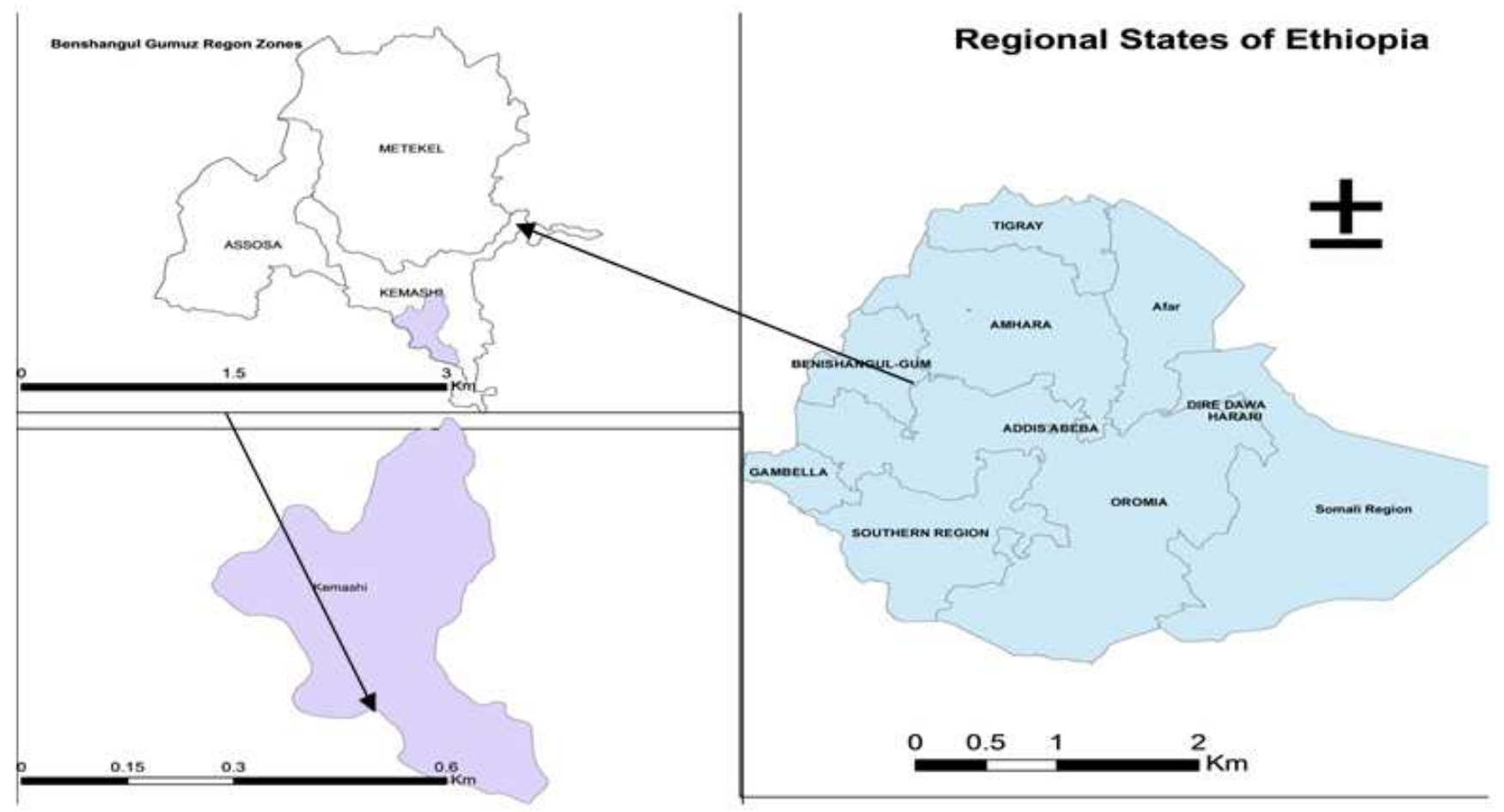

Figure 1. Map of the study area.

\subsection{Selection of Sites and Informants}

A purposive sampling method was employed to select six (6) kebeles from the Woreda, Ten (10) randomly selected informants and six (6) purposively selected key informants from each kebele with total of 96 informants from the Woreda following [7].

\subsection{Data Collection Methods}

Semi-structured interview, direct matrix ranking, focus group discussions, and guided field walks with informants were employed following [7-9] and field observation was carried out with local field guide assistant who have the skill of local language.

\subsection{Data Analysis}

Descriptive statistics, preference ranking, paired comparison, direct matrix ranking, and informant consensus were used to analyze the data.

\section{Result and Discussion}

\subsection{Taxonomic Diversity of Wild Edible Plants}

Total of 35 families, 49 genera with 60 species of WEPs were collected in the study area (figure 1). The family Fabaceae, Amaranthaceae and Acanthaceae were represented by the highest number of species (four species) or $(6.67 \%)$ followed by Malvaceae, Asteraceae and Zingiberaceae that contributed three species (5\%). Dioscoreaceae, Myrtaceae, Rubiaceae, Solanaceae, Tiliaceae, Rosaceae, Moraceae, Cucurbitaceae, Apocynaceae, and Vitaceae were the third in species diversity by having two species each (3\%) and nineteen of the remaining families were represented by single species each $(1.67 \%)$.

WEPs were also diversified interms of their growth forms and accordingly most of them are shrubs accounting for 
$36.67 \%$ followed by trees and herbs with $28.33 \%$ and $28.33 \%$ each. The least diversified wild edible plants in the area were found to be the climbers or lianas with $6.67 \%$ only (figure 2 ).

The result is different from the result obtained by [10] on wild edible plants in which the trees were the mostly consumed growth forms followed by shrubs and this difference may come from the ecological variances and vegetation type of the two sites.

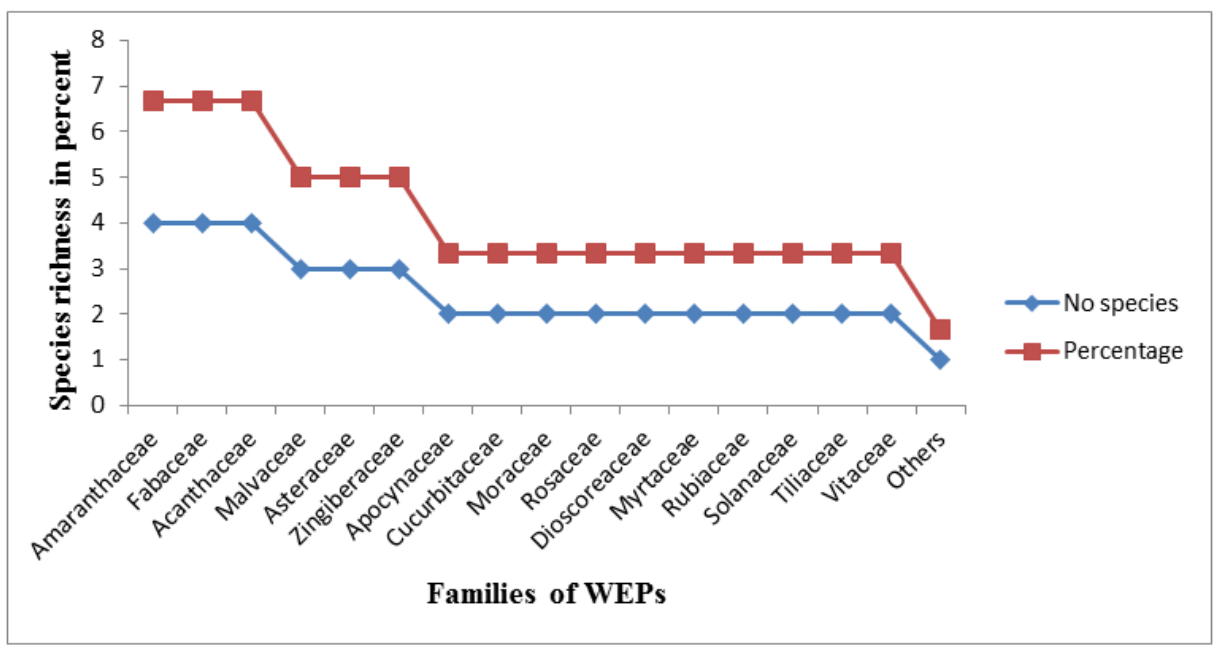

Figure 2. Taxonomic diversity wild edible plants in Kamash Woreda.

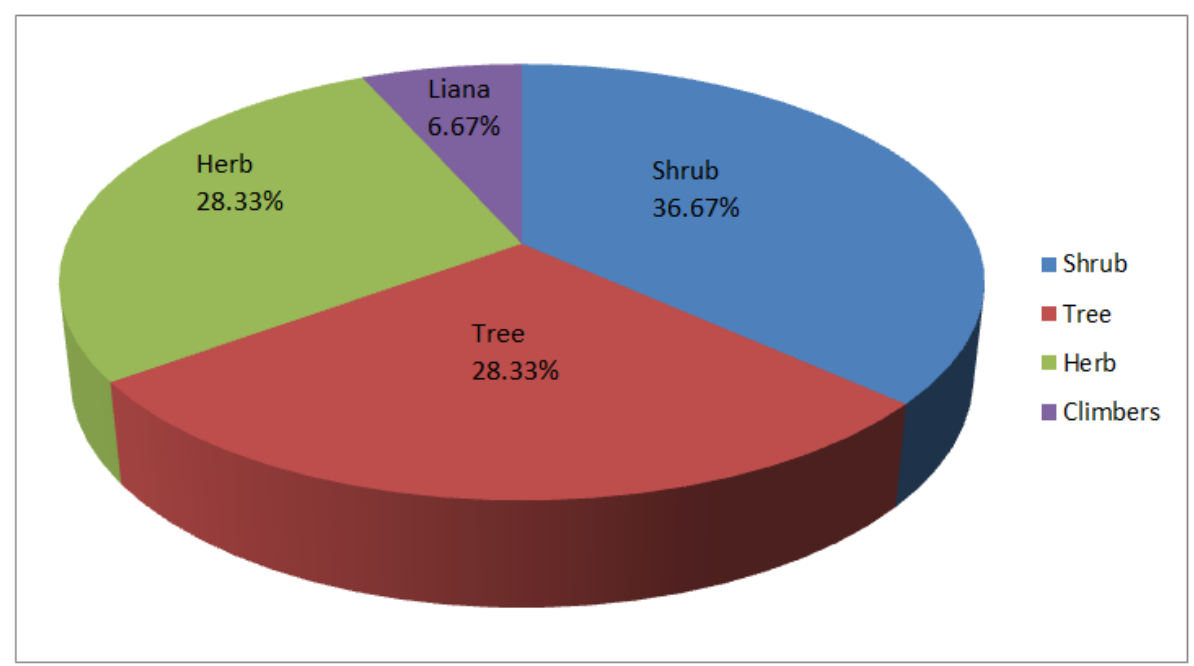

Figure 3. Wild edible plants diversity in their growth form.

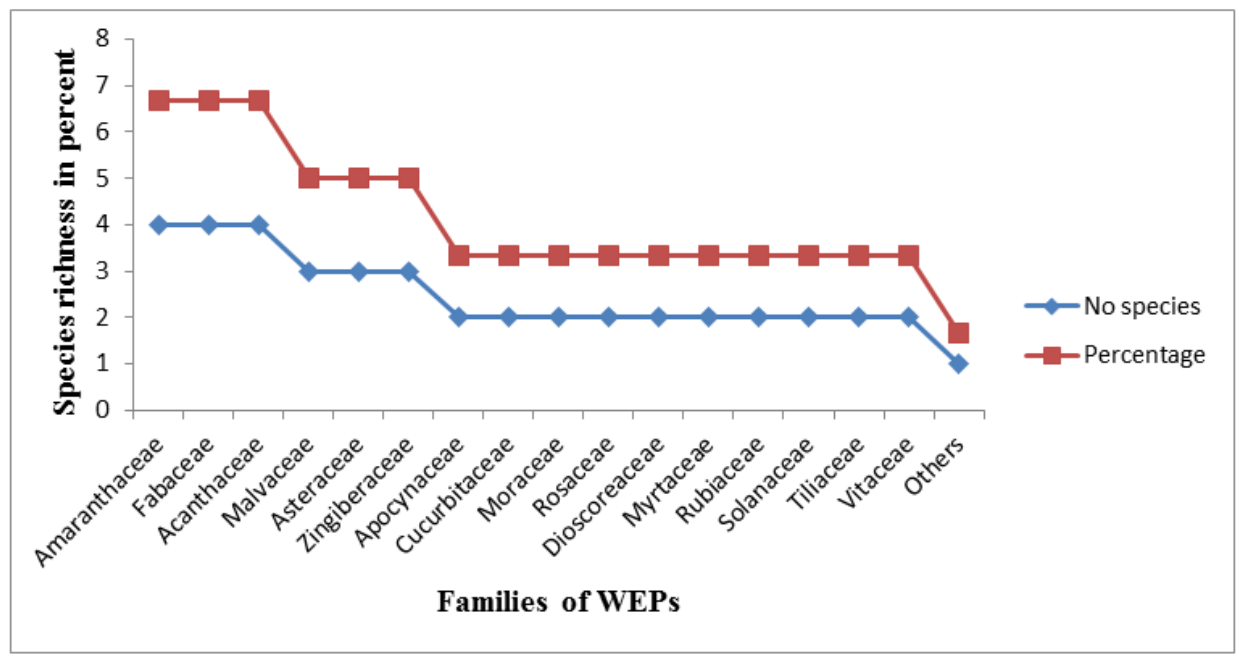

Figure 2. Taxonomic diversity wild edible plants in Kamash Woreda. 


\subsection{Edible Parts Wild Edible Plants}

From this study, 18 (30\%) fruit and 14(23.33\%) leaf were highly consumable parts of wild edible plants species by indigenous peoples of the study area. Tuber/Root $7(11.67 \%)$ and stem $5(8.33 \%)$ were next edible parts of the plants by the peoples. Seed 4(6.67\%), Flower, stem \& fruit, and fruit \& seedeach accounts for $3(5 \%)$, edible parts. The rest of parts like leaf and fruit, leaf and seed, and young bud and flower contributes $1(1.66 \%)$ each (figure 3$)$.

This result similar with the study conducted on wild edible plants at Kara and Kwego semi-pastoralist people in Lower Omo River Valley, Debub Omo Zone, SNNPR, of Ethiopia in which $23(58.97 \%)$ fruits, $13(33.33 \%)$ leaves, $3(7.69 \%)$ roots and one $(2.56 \%)$ seed were edible parts of the plants in the area [10]. Not only this but other studiesalso supports this result in which fruits were reported as the most utilized plant parts out of the total parts used [11-12]. The same result was reported by Regassa in which fruit $(40 \%)$ and fresh leaves $(17.5 \%)$ followed by shoots $(12.5 \%)$ were the most consumed parts of wild edible plants by Chellia peoples of Oromia Region, West-Central Ethiopia [13].

\subsection{Contribution of Wild Edible Plants in Food Security}

The general public consumes most of the WEPs as snacks, supplement or refreshments. So, most of the indigenous people of the area occasionally consider the WEPs as famine foods or foods in condition of starvation. According to the result from respondents, around $73.33 \%$ of the WEPs were used as supplementary food while the rest $(26.67 \%)$ were used as food regularly or as meal (table 3). Similar studies from other parts of Ethiopia; as well as from different parts of the world; reported that wild edible plants help to prevent starvation and sustain life during drought season and social unrest [14-17].

\subsection{Preference Ranking of Wild Edible Plants by Informants}

Species preference ranking of WEPs was conducted based on the informants' consensus approach to find out the relative importance of plants to the local community (Table 1). The most preferred species in increasing order were Oxythenantra abysinica, Abelmoschus esculentus, Corchorus olitorius, Dioscorea praehensilis, Annona senegalensis, Syzygium guineense and Luffa cylindrica. The species preference is almost similar throughout the kebele and there is no significant difference among the six kebeles. This may be due to similarity in ethnic composition and sharing of the same culture of wild edible plant utilization as well living the same Woreda. Oxythenantra abysinica was the most preferred edible plants, cited by most of respondents in all Kebele. Similarly, Abelmoschus esculentus and Corchorus olitoriuswere the best species cited by all respondents in all Kebeles as $2^{\text {nd }}$ and $3^{\text {rd }}$ in their preferencewhile Dioscorea praehensilis is fourth. Annona senegalensis and Syzygium guineense were postioned at fifth and sixth rank of the selected wild edible plants of the area while Luffa cylindrical got the last position. Selection and ranking of the most preferred candidate of wild edible plant, based on their taste and utilization by the indigenous peoples of the area. The FGD participants also reflectthe ranking.

Table 1. Results of preference ranking on seven most popular selected WEP species based their taste and repeated consumption by respondents of the study area $(1=$ least, $2=$ less, $3=$ good, $4=$ very good and $5=$ excellent $)$.

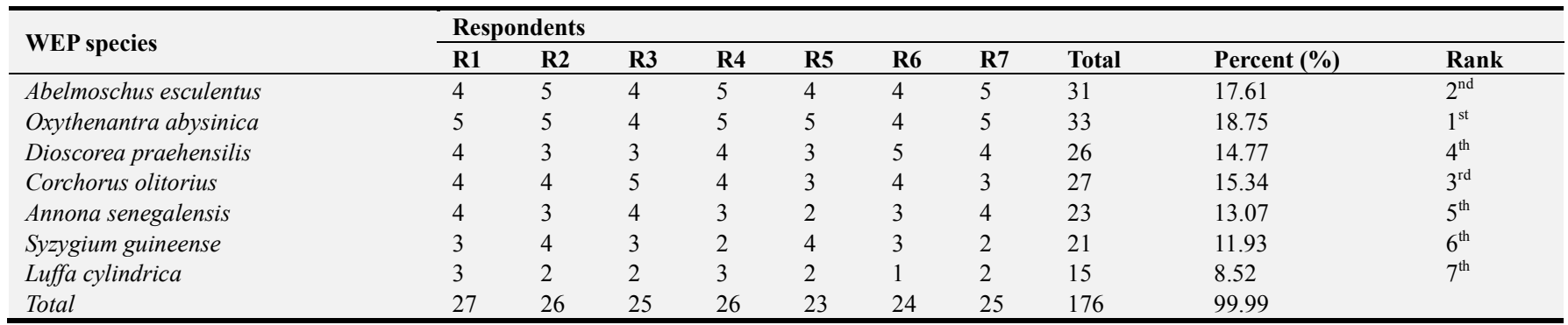

\subsection{Disaster Coping Mechanisms DuringFood Shortage/Poverty}

According to the responses from informants, using WEPs as sources food during famine is the first alternative to ensure food insecurity in the study area. It was stated as the wild foods from plants is not comparable to any other form mechanisms used to overcomefood insecurity for indigenous peoples of the Gumuz ethnic groups in the study area (table 2). Hunting, collecting and sale of firewood, collection and sale of incense, government employee as day laborer \& migration to other area are means of overcoming food insecurity.
The study conducted on Wild edible trees and shrubs in the semi-arid lowlands of Southern Ethiopia by Assefa and Abebe [19] supports the result of this study in that consumption of wild edible plant is the second mechanisms of coping with food insecurity in the area. The result of Guinand \& Lemessa, [20]; Balemie \& Kebebew, [4] on wild edible plants also revealed that, the consumption of wild food plants is ranked second as a coping mechanism for surviving during famine. The study conducted on Wild edible trees and shrubs in the semi-arid lowlands of Southern Ethiopia by Assefa and Abebe [19] supports the result of this study in that consumption of wild edible plant is the second mechanisms of coping with food insecurity in the area. 
Table 2. Respondents' means of overcoming food insecurity (60 informants).

\begin{tabular}{|c|c|c|c|c|c|c|c|c|}
\hline \multirow{2}{*}{ mechanism of handling food insecurity } & \multicolumn{7}{|c|}{ SampleKebeles } & \multirow[t]{2}{*}{ Rank } \\
\hline & Hena & Daguba & Mirmita & Gilgila & Kobi & Jalo Leka & Total & \\
\hline Consumption of WEPs & 4 & 4 & 5 & 3 & 4 & 3 & 23 & $1^{\text {st }}$ \\
\hline Looking for gov't help & 0 & 0 & 0 & 0 & 0 & 0 & 0 & $7^{\text {th }}$ \\
\hline Collection and sale of firewood \& charcoal & 1 & 2 & 2 & 1 & 2 & 2 & 10 & $3^{\text {rd }}$ \\
\hline Migration to other areas & 1 & 1 & 0 & 0 & 1 & 0 & 3 & $6^{\text {th }}$ \\
\hline Begging for food & 0 & 0 & 0 & 0 & 0 & 0 & 0 & $7^{\text {th }}$ \\
\hline Lookingfor employment as day-laborers & 1 & 1 & 0 & 1 & 0 & 1 & 4 & $5^{\text {th }}$ \\
\hline Hunting wild animals for meat & 2 & 2 & 2 & 3 & 2 & 3 & 14 & $2^{\text {nd }}$ \\
\hline Collection and sale of incense & 1 & 0 & 1 & 2 & 1 & 1 & 6 & $4^{\text {th }}$ \\
\hline Total & 10 & 10 & 10 & 10 & 10 & 10 & 60 & \\
\hline
\end{tabular}

\subsection{Paired Comparison}

For WEPs that were identified by the informants to be used as food, a paired comparison was made among five of them using ten informants to know their rank. Accordingly, Oxythenantra abysinica stood first followed by Ficus sur (table 3). This result indicates that Oxythenantraabysinicais much favored over other plant species cited in the study area as food plants. Moreover, the result could be a testimony for the efficacy of these two plant species to use as the most preferable food plants at least in the study area.

Table 3. Result of Paired comparison of WEPs used by the people of the area $(1=$ Least; $2=$ Good; $3=$ Very good; $4=$ Excellent.

\begin{tabular}{|c|c|c|c|c|c|c|c|c|c|c|c|c|}
\hline \multirow{2}{*}{ Plants species } & \multicolumn{10}{|c|}{ Respondents (R1-R10) } & \multirow[t]{2}{*}{ Total } & \multirow[t]{2}{*}{ Rank } \\
\hline & R1 & $\mathbf{R 2}$ & $\mathbf{R 3}$ & R4 & R5 & R6 & R7 & $\mathbf{R 8}$ & R9 & R10 & & \\
\hline Ficus sur & 2 & 3 & 3 & 4 & 2 & 3 & 2 & 2 & 2 & 1 & 24 & $2^{\text {nd }}$ \\
\hline Cordia africana & 3 & 2 & 2 & 2 & 1 & 2 & 3 & 1 & 2 & 3 & 21 & $3^{\text {rd }}$ \\
\hline Syzygium guineense & 1 & 3 & 2 & 2 & 1 & 3 & 1 & 1 & 2 & 2 & 18 & $4^{\text {th }}$ \\
\hline Oxythenantra abysinica & 4 & 4 & 3 & 4 & 4 & 3 & 4 & 4 & 4 & 3 & 37 & $1^{\text {st }}$ \\
\hline Amaranthus caudatus & 1 & 1 & 1 & 1 & 2 & 3 & 2 & 2 & 1 & 1 & 15 & $5^{\text {th }}$ \\
\hline
\end{tabular}

\subsection{Use Diversity of Wild Edible Plants}

Among the 60 WEPs documented in the study area, 48 plant species $(80 \%)$ were reported to have multipurpose roles while 12 of them $(20 \%)$ have only food role in the area (table 4). This finding shows that the local people harvest the wild edible plants of the area mostly for construction, firewood, and production of house hold equipment. The utilization of these plants for fire, construction and equipment is linked with the daily life activities of the community and the termination of their usage is impossible.

Table 4. Use diversity of wild edible plants in the study area.

\begin{tabular}{lll}
\hline Use & No of species & Percent (\%) \\
\hline Only food role & 12 & 20 \\
Food and firewood & 10 & 16.6 \\
Food and construction & 13 & 21.7 \\
Food and medicinal & 7 & 11.7 \\
Food and charcoal & 5 & 8.3 \\
Food and farm/house fence & 9 & 15 \\
Food and bee hive hanging & 4 & 6.7 \\
\hline
\end{tabular}

\subsection{Threats to and Conservation Status}

The ethno ecological knowledge on threats to WEPs and conservation concerns was also assessed. Like other plant species, WEPs are threatened due to various human activities and natural causes such as land use change (expansion of agricultural lands), developmental activities (road construction and urbanization); habitat destruction (timber harvest, fuel wood collection, wild fire); drought, overharvesting; and over-grazing were among the main factors that reduce the diversity and density of wild edible plants in the study area.

Although the potential impacts of climate change were also discussed; the respondents were reluctant to mention it as a major issue. It might be due to the fact that until recently the respondents did not experience and witness direct impacts of climate change on biodiversity.

To understand local people's perception on the factors more threatening WEP species with pair wise ranking of seven factors (agriculture, drought, and urbanization, fuel wood, wild fire, over grazing and selective cutting for construction) were conducted (table 5). The result indicated that agricultural activities and drought were ranked as first and second, while construction and over grazing was positioned at third and fourth stage followed by fuel wood, urbanization and wild fire which were ranked as fifth and sixth respectively. Similarly, the study conducted on Ethnobotanical study of wild edible plants in Derashe and Kucha Districts, Southern Ethiopia by Balemie and Kebebew [4] revealed that agricultural expansion as the principal threat to wild plant species. 
Table 5. Direct matrix ranking results of six respondents on six factors perceived as threats toWild edible plants (values: $1=$ least destructive, $6=$ most destructive).

\begin{tabular}{|c|c|c|c|c|c|c|c|c|c|}
\hline \multirow{2}{*}{ Threating factor } & \multicolumn{9}{|c|}{ Respondents } \\
\hline & R1 & $\mathbf{R 2}$ & R3 & R4 & R5 & R6 & Total & \%age & Rank \\
\hline Agriculture & 6 & 5 & 5 & 4 & 6 & 4 & 30 & 18.75 & $1^{\text {st }}$ \\
\hline Extended dry time & 4 & 5 & 6 & 3 & 5 & 5 & 28 & 17.5 & $2^{\text {nd }}$ \\
\hline Urbanization & 3 & 2 & 3 & 1 & 3 & 4 & 16 & 10 & $6^{\text {th }}$ \\
\hline Overgrazing & 4 & 4 & 3 & 5 & 5 & 3 & 24 & 15 & $4^{\text {th }}$ \\
\hline Construction & 5 & 5 & 4 & 3 & 4 & 5 & 26 & 16.25 & $3^{\text {rd }}$ \\
\hline Fuel wood & 3 & 4 & 3 & 4 & 2 & 4 & 20 & 12.5 & $5^{\text {th }}$ \\
\hline Wild fire & 4 & 2 & 3 & 2 & 2 & 3 & 16 & 10 & $6^{\text {th }}$ \\
\hline
\end{tabular}

\section{Conclusion}

The result of the study revealed that knowledge about the edibility, habitat distribution, harvesting time and uses of most wild edible plant species is still preserved among the study communities. The preservation of this knowledge appears to be the result of continued reliance of local communities on the wild edible plants and it's passed from elders to younger's orally. Analysis of the results showed that in all study kebeles, most of the edible plants were used mainly by all communities during normal and shortage of food. Utility of the wild edible plants especially by children of the community members indicated the maintenance of indigenous knowledge associated with the plant species in the area. But the diversity of wild edible plants in the area is declined gradually by different factors leading to the fading away of this indigenous knowledge associated with the plants of the area. The results also showed that many wild edible species are under growing pressures from various anthropogenic factors. Thus, public awareness and community based management need to be encouraged by government and non government organizations at all levels with urgent collection of Germplasm by the professionals. The findings suggest further investigation into nutritional profiles and processing methods of all the species reported and study of the pharmacological properties for the nutraceutical species since they are also used for medicinal applications.

\section{Recommendation}

Based on the results of the study, the following recommendations are forwarded:
1. Local communities should be encouraged to cultivate wild food plants on their own land. Provision for technical as well as financial assistance should be made in this regard.

2. Raising awareness of the young generation to avoid negative impacts on wild edible plants and associated knowledge. So that the plants and the TK would be preserved.

3. The indigenous knowledge and skill of using wild edible plants must be encouraged and protected.

4. Establishing conservation measures and strategies to ensure the sustainability of multipurpose and widely used wild edible plants is needed as most them are obtained from the wild. This can be achieved by:

(a). Encouraging people to grow wild edible plants in the home gardens, mixing with crops in farmlands and live fences.

(b). Promoting the establishment of local botanical garden starting at least at the Woreda level.

5. Since some of the highly valued wild edible plants are being over exploited due to their use for food purposes, specific wild food plant conservation strategy should be formulated and implemented for long term management of plants in the area.

6. A long term research and monitoring on ethnobotany and its practices on other wealth of useful plants from the forests and surroundings is imperative.

7. The findings suggest further investigation into nutritional profiles and processing methods of all the species reported and study of the pharmacological properties for the nutraceutical species since they are also used for medicinal applications.

\section{Appendix}

Table 6. Local name, scientific name, parts used and habit of Collected WEP Species in the Study Area.

\begin{tabular}{|c|c|c|c|c|c|}
\hline No & Local name(Gumuz) & Family & Scientific name & Parts used & Habit \\
\hline 1 & Andegila & Bignoniaceae & Stereospermum kunthianum Cham. & Young stem & Shrub \\
\hline 2 & Agidema & Asteraceae & Vernonia theophrastifolia schweinf.ex Oliv\& Hiern & Leaf & Shrub \\
\hline 3 & Ajanzibil & Zingiberaceae & Zingiber officinale Roscoe & Root & Herb \\
\hline 4 & Akala & Fabaceae & Vigna subterranea (L.) Verdc. & Seed & Shrub \\
\hline 5 & Akechechile & Amaranthaceae & Amaranthus caudatus L. & Cooked Leaf & Herb \\
\hline 6 & Ambershuwa & Amaranthaceae & Celosia trigyna L. & Cooked Leaf & Herb \\
\hline 7 & Andedha & Malvaceae & Abelmoschus esculentus (L.) Moench. & Fruit & Shrub \\
\hline 9 & Anjidema & Asteraceae & Vernonia theophrastifolia Schweif.ex Oliv.\& Heirn & Leaf & Shrub \\
\hline
\end{tabular}




\begin{tabular}{|c|c|c|c|c|c|}
\hline No & Local name(Gumuz) & Family & Scientific name & Parts used & Habit \\
\hline 10 & Antsiqina & Vitaceae & Ampelocissus schiperiana (L.) weight \& Arn & Young stem & Shrub \\
\hline 11 & Antsitsa & Flacourtiaceae & Oncoba spinosa Forssk. & fruit \& young stem & Shrub \\
\hline 12 & Baga & Brassicaceae & Brassica carinata $A . B r$ & Leaf & Shrub \\
\hline 13 & Bakeya & Rubiaceae & sarcocephalus latifolinus (J. E. Smith) E. A & fruit & Tree \\
\hline 14 & Bambeya & Convolvulaceae & Ipomea batatas $L$. & Root & Liana \\
\hline 15 & Bambuta & Annonaceae & Annona senegalensis Pers. & fruit & Tree \\
\hline 16 & Banja & Boraginaceae & Cordia africana Lam. & fruit & Tree \\
\hline 18 & Beewa & Fabaceae & Lonchocarpus laxiflorus Guill. \& Perr. & Grinned flower & Tree \\
\hline 19 & Bela & Portulaceae & Portulaca oleracea & Leave \& seed & Shrub \\
\hline 20 & Bishela & Apiaceae & Anethum graveolens $L$. & Flower & Shrub \\
\hline 21 & Boha & Acanthaceae & Acanthus pubescens (Oliv.) Engl. & Flower & shrub \\
\hline 22 & Chichariya & Amaranthaceae & Amaranthus spinosus L. & Leave & Shrub \\
\hline 23 & Darguwa & Acanthaceae & Asystasia gangetica (L.) T.Andress. & Cooked leaf & Herb \\
\hline 24 & Diwa & Myrtaceae & Syzygium guineense (Willd.) DC. subsp guineense & fruit & Tree \\
\hline 27 & Eca & Dioscoreaceae & Dioscorea praehensilis Benth. & root & Liana \\
\hline 28 & Echa & Moraceae & Ficus sur Forssk. & Fruit & Tree \\
\hline 29 & Ejega & Malvaceae & Hibiscus sabdariffa L. & Fruit \& seed & Shrub \\
\hline 30 & Ejimbeya & Anacardiacaea & Ozoroa pulcherrima (Schweinf.) R.\& A. Fernand & Stem & Herb \\
\hline 31 & Ejisiya & Solanaceae & Physalis peruviana $\mathrm{L}$. & Young bud \&Flower & Tree \\
\hline 32 & Ekicanqila & Amaranthaceae & Amaranthus hydridus & Cooked leaf & Herb \\
\hline 33 & Elangiya & Acanthaceae & Justicia ladanoides Lam. & Cooked Leaf & Herb \\
\hline 34 & Ewa & Vitaceae & Cissus populnea Guill. \& Perr. & Leaves & Shrub \\
\hline 35 & Feya & Olacceae & Ximenia Americana L. & Fruit & Tree \\
\hline 36 & Gediya & Tiliaceae & Grewia mollis A. Juss & Fruit & Tree \\
\hline 37 & Hafa & Combretaceae & Combretum collinum Fresen. & Seed & Tree \\
\hline 38 & Hanguga & Rhamnaceae & Ziziphus abyssinica Hochst ex A. Rich & Fruit & Tree \\
\hline 39 & Heca /qilxu & Moraceae & Ficus vasta Forssk. & Fruit & Tree \\
\hline 40 & Heya & Olacaceae & Ximenia americana L. & fruit & Herb \\
\hline 41 & Hojiya /enta & Poaceae & Oxythenantra abysinica (A. Rich) Munro & Young stem & Herb \\
\hline 44 & kompha & Araceae & Colocasia esculenta (L.) Schott. & Root & Herb \\
\hline 45 & Kota & Rubiaceae & Gardenia ternifolia Schum. \& Thonn. & fruit & Tree \\
\hline 46 & Lalqa & Tiliaceae & Corchorus olitorius L. & Leaf & Shrub \\
\hline 47 & Mecha & Fabaceae & Piliostigma thonningii & fruit & Tree \\
\hline 48 & Molowa/Metiya & Arecaceae & Phoenix reclinata Jacq. & Young stem \&fruit & Herb \\
\hline 49 & Ola & Zingiberaceae & Aframomum alboviolaceum (Ridl.) K. schum & Raw root & Herb \\
\hline 50 & Muga & Acanthaceae & Justicia schimperiana (Hochst.ex Nees) T. Anders & Flower & Shrub \\
\hline 51 & Qoqora & Verbenaceae & Vitex doniana Sweet. & Ripped fruit & Tree \\
\hline 52 & Qosha & Euphorbiaceae & Ricinus communis L. & Seed & Shrub \\
\hline 53 & Siwa & Apocynaceae & Carissa spinarum $\mathrm{L}$. & Fruit & Shrub \\
\hline 54 & Shawa & Myrtaceae & guineense (Willd.) DC. supsp afromontanum & fruit & tree \\
\hline 55 & Waga & Rosaceae & Rubus steudneri Shweinf. & Fruit & Shrub \\
\hline 56 & Xasha & Celastraceae & Maytenus senegalensis (Lam.) Exell. & Burned stem as salt & Herb \\
\hline 57 & Yampedema & Zingiberaceae & Costus spectabilis (Fenzl) K. schum & Root & Shrub \\
\hline 58 & Yechiwa & Dioscoreaceae & Dioscorea bulbifera & Root & Liana \\
\hline 59 & Sinada & Rosaceae & Rubus apetalus Poir. & fruit & Shrub \\
\hline 60 & Equmetsa & Cucurbitaceae & Peponium vogelii (Hook.f.) Engl. & Fruit & Herb \\
\hline
\end{tabular}

\section{References}

[1] Ju, Y., Zhuo, J., Liu B. and Long, C. Eating from the wild: diversity of wild edible plants used by Tibetans in Shangri-la region, Yunnan, China. Journal of Ethnobiology and Ethnomedicine (2013); 9:28

[2] Food and Agricultural Organization. Forests for Improved Nutrition and Food Security (2010).

[3] Hunter, D. and Fanzo, J. Agricultural biodiversity, diverse diets and improving nutrition (2013). London, Earth scan publishers.
[4] Balemie K and Kebebew F. Ethnobotanical study of wild edible plants in Derashe and Kucha Districts, South Ethiopia. $J$ Ethnobiol and Ethnomed. (2006). 2:53

[5] Lulekal E, Asfaw Z, Kelbessa E and Damme, V. P. Wild edible plants in Ethiopia: a review on their potential to combat food insecurity (2011).

[6] Central Statistical Authority. National Population and Housing Census of Ethiopia. Addis Ababa (2007).

[7] Martin GJ. Ethnobotany: A methods manual. Chapman and Hall, London; (1995).87-105

[8] Cotton, C. M. Ethnobotany: Principles and Applications. John Wiley and Sons, New York, (1996). 412. 
[9] Alexiades, M. N. Collecting ethnobotanical data: An introduction to basic concepts and techniques. Selected Guidelines for Ethnobotanical Research: A Field Manual. The New York Botanical Garden, Bronx, New York (1996). 53-94.

[10] Teklehaymanot T. and Giday M. Ethnobotanical study of wild edible plants of Kara and Kewego semipastoralist people in Lower Omo River valley, Debub Omo Zone, SNNPR, Ethiopia. J Ethnobioland Ethnomed (2010). 6: 23.

[11] Tamene B, Bekele T, and Kelbessa E. An Ethnobotanical Study of the Semi-Wetland Vegetation of Cheffa. Addis Ababa University Press, Addis Ababa, Ethiopia, 2000, http://www.pheethiopia.org/pdf/Hujub\%20Sacred\%20Forests.pdf.

[12] Wondmu T, Asfaw Z and Kelbessa E. Ethnobotanical study of foodplants around deeraa town arsi, Ethiopia. SINET: Ethiopian. Journal of Science. (2006). 29(1):71-80.

[13] Regassa T, Kelbessa E and Asfaw Z. Ethnobotany of Wild and Semi- Wild Edible Plants of Chelia District, West-Central Ethiopia; Sci. Technol. Arts Res. J., (2014).3(4): 122-134.

[14] Zemede A. Indigenous African food crops and useful plants:
Survey of indigenous food crops, their preparations and home gardens Nairobi: The United Nation University Institute for Natural Resources in Africa. (1997).

[15] Awas T. Plant diversity in western Ethiopia: Ecology, Ethnobotany and Conservation (1997).

[16] Neudeck L, Avelino L, Bareetseng P, Barbara Ngwenya N, Teketay D and Moseki R. Journal of Ethnobotany Research \& Applications (2012).(10):449-462.

[17] Cunningham, A. B. Applied Ethnobotany: People, Wild Plant Use and Conservation. People and Plant Conservation manual. Earth scans Publication Ltd. (2001). 145

[18] Grivetti, L. (2001). Reading 8: Edible Wild Plants, Part 1, issued on 15/10/2016. http://www.ucdavis.- edulGrivetti.htm

[19] Assefa A \& Abebe T. Wild Edible Trees and Shrubs in the Semi-aridLowlands of Southern Ethiopia. Journal of Science \& Development (2011). 1: 5-19.

[20] Guinand, Y. and Dechassa L. Wild-food plants in Southern Ethiopia: Reflections on the role of famine-foods at a time of drought. UNDP-EUE. Field mission report, Addis Ababa. (2000). 